\title{
A Review on Potentiality of Industry 4.0 in Nepal: Does the Pandemic Play Catalyst Role?
}

\author{
Sharad Rajbhandari ${ }^{1} \odot$, Ghanashyam Khanal ${ }^{*} \odot$, Seeprata Parajuli ${ }^{\circledR}$, \\ Dipendra Karki ${ }^{4}$ ()
}

1 MBA Graduate, Quest International College, Pokhara University, Lalitpur, Nepal

2 Faculty, Department of Economics, Morgan International College, Tribhuvan University, Kathmandu, Nepal

3 Research Management Cell, Quest International College, Pokhara University, Lalitpur, Nepal

4 Assistant Professor, Nepal Commerce Campus, Tribhuvan University, Nepal.

" Corresponding Author (gskhanal44@gmail.com)

Received: 17 June, 2020

Revised: 29 August, 2020

Accepted: 18 October, 2020

Published: 15 December, 2020

How to cite this paper:

Rajbhandari, S. Khanal, G., Parajuli, S., \& Karki, D. (2020). A review on potentiality of industry 4.0 in Nepal: Does the pandemic play catalyst role? Quest Journal of Management and Social Sciences, 2(2), 3557-370.

Copyright (C) 2020 by authors and Quest Journal of Management and Social Sciences.

This work is licensed under a Creative Commons Attribution-Non Commercial-No Derivatives 4.0 International License. https://creativecommons.org/ licenses/by-nc-nd/4.0/

\section{Abstract}

Background: Industry 4.0 is the revolution of industrial process along with the adaptation of technological changes and advancement. With the passage of time industry 4.0 has been catching the attention of industries all over the world. Various studies and literatures seem to be emerging regarding industry 4.0 around the globe. However, in Nepalese context no study has been conducted on the particular field.

Objective: This study aims to study the current status of industries in Kathmandu valley and analyzes the factors affecting industrial readiness for industry 4.0 amidst the effects of the pandemic. It tries to review the industrial readiness for industry 4.0 in Nepal.

Methods: Systematic literature review was conducted to analyze various literatures around the world along with 20 empirical reviews to make this study more efficient. Also, conceptual framework was developed to draw roadmap of the study.

Results: We found that Nepal has got many problems in adoption of the concept of Industry 4.0. Our study noticed that along with the involvement of much unskilled labor force in industries, lack of infrastructural development and innovation, and ineffective government policy are the vital ones.

Conclusion and implication: This study concludes that Nepal has huge unskilled workers relatively to skilled workers that are means for adaptation of new technologies, replacing manual work and the government from policy level needs to focus on this. This study will be beneficiary for Ministry of Information and technology, Ministry of industry, Ministry of Education, Health and science, Policy makers, Foreign as well as domestic investors, and for authors and graduating students in understanding industries readiness for 4.0 in Nepal.

Keywords: Industries, Industry 4.0, Nepal, Nepalese industries, Readiness

Paper Type: Review Paper

JEL Classification: L6, L16 


\section{Introduction}

In recent years, the word "Industry 4.0" has become a topic of growing importance. This idea was first published by German government in November 2011 as a part of a High Technology Strategy Plan for 2020 (Zhou, Liu, \& Zhou, 2016). The global industrial scenarios are changing dramatically in recent years due to the innovation and developments in manufacturing processes. Over recent years, numerous new global trends have arisen with the growing advancement over production processes and technologies. Industry 4.0 can be tentatively linked to three revolutions in recent centuries which are the latest transformative productivity shifts arising from multiple technological developments (Schmidt et al., 2015).

The first industrial revolution was brought and facilitated by the invention of the steam engine in Britain in mid-18th century. The Second Industrial Revolution was witnessed in Europe and the USA in the second half of the 19th century. Mass production and the substitution of steam with chemical and electrical technology are indicative of this transition. In order to accomplish more manufacturing efficiency it is necessary to use electronics and IT that this movement occurred in many developed nations around the world over the last years of the 20th century (Daron, 2002).

The heart of every industrial revolution is to increase productivity in a low cost. The first three industrial revolutions had an important impact on industrial processes that improved operational efficiency by using disruptive technology innovations such as steam engine technology, electricity or digital technology (Schuh, Potente \& Hauptvogel, 2013). Industry 4.0 is a new technical framework that has been widely debated and studied and is likely to eventually constitute a fourth industrial revolution because it provides significant progress relevant to intelligent and potential industries in the market. The new concept of Industry 4.0 is the corner stone to a new industrial model that covers a range of industry technologies including cyber-physical systems (CPS), the Internet of things (IoT), Internet of services (IoS), robots, big data and cloud computing (Schuh et al., 2013). The new approach brings digital and physical environments together through CPS technologies, opening up a range of potential markets that will allow the businesses embracing the new production model to increase productivity and efficiency (Zhou et al., 2016).

Nepal introduced open policies for improving trade conditions in the mid-1980s, reducing external dependence and creating jobs, but failed to achieve the aforementioned aims. Nonetheless, that dependence on foreign markets to satisfy the rising need for capital goods and intermediate inputs was an obstacle to the growth of manufacturing because of the capital-intensive existence of the IS industries. Since late 1950s, Nepal has carried out regular economic plans. However, the low level of mobilization of domestic resources, unsatisfactory external aid payments, and poor project management were primarily attributed to low production capacity, although government spending has been growing (Mainali, 2017).

The general belief the liberalizing economy enhances internal and external competition, thereby improving the productivity of the private sector. As a result, liberalization began at the start of the financial-sector reform in the middle of the 1980s, but a massive liberalization actually began in the 1990s (Mainali, 2017). CBS (2014) shows Nepal ranks 119th out of 135 countries in the Sustainable Industrial Performance Index (CIP). According to Economic Survey (2018) the number of industries was 7832. Out of these registered industries, Two-thirds of the industries are recorded in Bagmati Pradesh and the lowest number in Karnali Pradesh until mid-March of the FY 2018/19. This evidence states the slow pace of industrial development in Nepal as well as the weak situation of the industrial sector in Nepal.

Indeed, the current COVID-19 pandemic which originated from Wuhan of China in December 2020 poses a wide range of challenges for industries as it has huge impact in others sectors too. Depending on a series of factors, like the nature of the business, employee readiness, home environment and tools, 
cultural behavior, some companies will be able to keep up productivity; while others won't. In a mid to long-term situation, workforce transformation requirements will imply support of near-real-time tasks. Some examples include self-driven cars, robots for manual activities, digital twins and holographic work collaboration. AI and biotechnology applied massively to the health sector can help in the current pandemic and many other diseases that today have not treatment. The possibilities are endless, beyond what we can imagine today, although some of them have already been raised (like neural technologies and others).

The industries and commerce from different sectors will drastically change. Restaurants might use drones for delivery, venues could offer remote visits based on VR, and automobile companies may invest in driverless cars for public and private transportation. All these network and technology requirements that come along with the fourth industrial revolution may be accelerated by the current pandemic.

From all above evidence, we acknowledge that Nepal's industries are least developed. Thus, concerning all rationale, this study is focused to measure industrial readiness for industry 4.0. Based on above statement of problem, the study questions for this study are as follows; i) what is the current status of industries in Kathmandu valley?, ii) what is the factor affecting industrial readiness for industry 4.0?, and what are the obstacles of implementing industry 4.0? Therefore, this study will be beneficiary for Ministry of Information and technology, Ministry of industry, Industry department, Ministry of Education, Health and science, Policy makers, Foreign as well as domestic investors, and for authors and graduating students in understanding industries readiness for 4.0 in Nepal.

Further, this study is categorized as follow: Section 2 includes literature of review followed by discussion and research gap in section 3 and section 4 concludes the study.

\section{Review of Literature}

\section{Industry 4.0}

Industry 4.0 is a burning issue all over the world. It is the technique that uses the power of creative technologies and computing technologies to foster the manufacturing industry's growth (Kagermann et al., 2013). Industry 4.0, by collecting data intelligently, making right decisions and enforcing decisions without any reservations, promotes production efficiency. The methods of gathering and analyzing information become simpler by using the technologically advanced technologies. The functional interoperability feature serves as a 'connecting link' to provide a stable development environment for Industry 4.0. The main element of artificial intelligence operation is the general understanding of industry 4.0 (Qin, Liu, \& Grosvenor, 2016).

Industry 4.0 is enmeshed in the entire value chain by a vast network of advanced technology. A brand new era in manufacturing processes is bringing in service, automation, artificial intelligence robotics, Internet of Things and additive manufacturing. The distinctions between real world and virtual reality blur and trigger the cyber-physical production systems (CPPS) phenomena (Schumacher, Erol, \& Sihn, 2016). Industry 4.0 separates itself from a few new technology features, such as physical, digital and biological environments. Technological improvements have major impacts on the economies, industries and development plans of the government. Schwab noted Industry 4.0 as one of the key concepts for global industry and global economy development (Lee et al., 2018).

Industry 4.0 uses emerging technologies to address global challenges, as well as rapid machinery and tools to improve industry levels. Industry 4.0's primary idea is to use modern IT technologies to implement IoT products. By integrating engineering knowledge, production can work faster and easier with minimum downtimes. The material produced will therefore be of better quality, production systems will be more effective, easier to maintain and save costs (Wang, Wan, Li, \& Zhang, 2016). With the advancement of computers, and software, networked sensors can be utilized to schedule, anticipate, 
change and monitor the societal outcome and business models, and can be controlled throughout the entire product process, adding another step of the value chain in organizations.

\section{Evolution of Industrial Revolution}

The industrialization cycle started at the end of 18th century with the advent of electric processing machinery (Kagermann et al., 2013). Machines and engines revolutionized the way howproducts were made, powered by James Watt's invention of the steam engine. It was initiated the transition from a rural to an urban society. The first industrial revolution contributed tremendously to the decrease in famine disasters and the consequent growth in population explosion in developing countries (Bauernhansl, 2014).

Second industrial revolution then pursued which began at the turn of 20th century and featured electrically-powered mass manufacturing of goods based on labor division (Kagermann et al., 2013). The transition arrived primarily from systemic changes such as the adoption of the assembly line of Henry Ford and modern management methods based on the Taylorism by Frederic W. The massproduction sector was expanded and particularly evolved in the chemical, electrical, mechanical and automobile sectors. Thus, consumer manufacturing business has been more comprehensive (Bauernhansl et al., 2014).

Third industrial revolution which began in the early 1970s and continued right up to the present day replaced this growth. The transition is marked by the implementation of electronics and IT to improve the efficiency of industrial operations when robots take up a large proportion of labor and eventually replace them. The effects of mechanization, automation and, last but not least, information technology (IT) can be summarized in the order of the first three technological revolutions. According to Kagermann et al. (2013), a fourth technological revolution is being launched with the implementation of the system of information (IoT) and infrastructure (IoS) into the production environment.

\section{Industrial Revolution in Nepal}

Nepal's search for industrialization dates back to mid-1930s with the state intervention, the then Rana regime established a host of public enterprises (PEs). Although half of the PEs were manufacturing related, the remainder were retail, trade, public facilities and the financial sector. The oldest industry, the ailing Biratnagar Jute Mill, was formed in 1936. It was also the milestone launch of Nepal's modernization. The first industrial estate was built in Balaju, Kathmandu under the help of United States in 1960 (B.K. et al., 2019). In 1990, after the re-establishment of multiparty democracy that was supposed to create a pro-business climate conducive to the industrial boom, new hope of industrial revolution was ignited. The initial years showed some signs of improvement, but since then the agenda of neo-liberalization have turned out to be totally off the mark. The blind privatization led to many profit-making PEs being shut down after being sold at a throwaway price to private companies. Afterwards, Maoist insurgency resulted too expensive for the fledgling industrial sector of the country. Rebels damaged vital infrastructures including telecommunications, hydropower, bridges, and public buildings. Now, new federal government has called for strong economic growth using the favorable political climate. The government is putting its best foot forward with enabling laws and incentives to attract foreign investors to pour their money into many a virgin area of economy. To this end, Nepal's Investment Board, headed by the Prime Minister himself, was created to serve as an effective agency. To grow all the states, the Government has floated the idea of 'One Province One Big Industrial Estate'.

Government of Nepal has developed eleven Industrial estates under the guidance of various donor countries such as the United States, India, the Netherlands and Germany. Out of eleven estates 10 (Balaju, Patan, Hetauda, Dharan, Nepalgunj, Pokhara, Butwal, Bhaktapur, Birendranagar and Gajendra Narayan Singh (Rajbiraj) are in operation and due to technical problems Dhankuta is not currently operated. And three new industrial sectors Naubasta, Mayurdhap and Daman are under construction. 


\section{Status of Industrial States}

Kathmandu Valley, capital of Nepal consists of three industrial estates: Industrial estate of Balaju, industrial estate of Bhaktapur and Industrial sectors of Patan (B.K. et al., 2019). Bhaktapur industrial estate occupied 71, 28 ropanies and all land had been fully developed, with 35 industries in operation out of 36 industries. Patan industrial state has a total area of 293 ropanies. Similarly, the area of operations contained 73 ropanies. The district actually has 118 factories, of which 118 are in operation. Balaju industrial estate comprises 670 ropnies of land, of which 540 ropanies have been well-developed. There are 146 industries in this estate out of which 134 are in operation.

As we hold on the brink of the Fourth Industrial Revolution, innovation will be the major driver of economic progress. If the current political and bureaucratic set-up will prepare the country for the Fourth industrial revolution is yet to be seen. If the government intends, it must integrate the nation with the dynamics of the modern techno-economic world by embracing disruptive innovation, for the himalayan nation's ability to develop and carry technologies to market successfully, which would be a crucial determinant of global competitiveness. But, if industries of Nepal doesn't move forward to the path of growth following technological advancement, it will most likely stay trapped in poverty even as it did in the first, second and third industrial revolutions. However, stepping forward with industrial competitiveness, Nepal will integrate creativity, science and technology into national economic policies, albeit with Silicon Valley's mentality (Devkota and Shah, 2016).

Table 1: Status of Industrial Estates

\begin{tabular}{lccc}
\hline \multicolumn{1}{c}{ Industrial District } & Bhaktapur & Patan & Balaju \\
\hline Estd. year (AD) & 1979 & 1963 & 1960 \\
No. of Industries & 36 & 118 & 141 \\
Area (ropani) & 71.78 & 293 & 670 \\
Running & 35 & 118 & 97 \\
Under construction & 0 & 0 & 0 \\
Closed & 1 & 5 & 44 \\
\hline
\end{tabular}

Source: Industrial District Management Limited

Up to now, Nepalese remain busy juggling never stopping global transformations, constantly unfolding. Nepalese people own more mobile phones than toilets; however, given the country's political situation, there is a greater chance that we might miss the fourth industrial revolution (Manadhar, 2017). In this scenario, initiatives where people receive a digital workshop and are trained, prepared to adapt to the changing face of technology or automation. This also enhances everybody's technological and automation knowledge which is one of the major hindrances in Nepalese industries (Ghimire, 2020).

\section{Empirical Studies on Industrial Revolution}

Various empirical literatures were reviewed in order to make this study more efficient. Studies conducted are showcased with the help of table below:

Table 2: Empirical Review

\begin{tabular}{|c|l|l|l|}
\hline \multicolumn{1}{|c|}{ Authors } & \multicolumn{1}{|c|}{ Topic of Research } & \multicolumn{1}{|c|}{ Result /Findings } & \multicolumn{1}{c|}{$\begin{array}{c}\text { Conclusion/ } \\
\text { Recommendation }\end{array}$} \\
\hline Jazdi (2014) & $\begin{array}{l}\text { Cyber physical } \\
\text { systems in the Context } \\
\text { of Industry 4.0 }\end{array}$ & $\begin{array}{l}\text { The specification for the } \\
\text { institute of industrial } \\
\text { automation and digital } \\
\text { engineering showed the } \\
\text { value of Industry 4.0. }\end{array}$ & $\begin{array}{l}\text { The future research depends } \\
\text { on a centralized network } \\
\text { computer agent-based remote } \\
\text { access. }\end{array}$ \\
\hline
\end{tabular}




\begin{tabular}{|c|c|c|c|}
\hline Authors & Topic of Research & Result /Findings & $\begin{array}{c}\text { Conclusion/ } \\
\text { Recommendation }\end{array}$ \\
\hline $\begin{array}{l}\text { Wan et al. } \\
(2015)\end{array}$ & $\begin{array}{l}\text { Industry 4.0: Enabling } \\
\text { technologies }\end{array}$ & $\begin{array}{l}\text { Technologies play an } \\
\text { important role in traditional } \\
\text { industry's development and } \\
\text { transformation. }\end{array}$ & $\begin{array}{l}\text { Modern strategies, emerging } \\
\text { technology, new needs and } \\
\text { emerging fashion should be } \\
\text { used in order to make our } \\
\text { environment smart, green and } \\
\text { urban. }\end{array}$ \\
\hline $\begin{array}{l}\text { Weyer et al. } \\
(2015)\end{array}$ & $\begin{array}{l}\text { Towards industry } 4.0 \\
\text { - Standardization as } \\
\text { the crucial challenge } \\
\text { for highly modular, } \\
\mathrm{m} \mathrm{u} 1 \mathrm{t} \mathrm{i}-\mathrm{v} \text { e } \mathrm{n} \mathrm{d} \text { o r } \\
\text { production systems }\end{array}$ & $\begin{array}{l}\text { The integration of material } \\
\text { flow into the production } \\
\text { modules themselves } \\
\text { presents several problems. }\end{array}$ & $\begin{array}{l}\text { In the next couple of years, } \\
\text { require new qualifications. } \\
\text { By designing and offering } \\
\text { effective teaching and testing } \\
\text { tools, the industrial partner } \\
\text { takes this aspect into account. }\end{array}$ \\
\hline $\begin{array}{l}\text { Schumacher } \\
\text { et al. (2016) }\end{array}$ & $\begin{array}{l}\text { A maturity model for } \\
\text { assessing industry } 4.0 \\
\text { readiness and maturity } \\
\text { of manufacturing } \\
\text { enterprises }\end{array}$ & $\begin{array}{l}\text { The present research work } \\
\text { was designed to develop } \\
\text { a maturity model and } \\
\text { an associated tool for } \\
\text { evaluating the maturity } \\
\text { of manufacturing firms in } \\
\text { Industry 4.0. }\end{array}$ & $\begin{array}{l}\text { Future research will primarily } \\
\text { aim at identifying target } \\
\text { states for specific companies, } \\
\text { improving the precision of } \\
\text { maturity items, and defining } \\
\text { strategic steps to achieve the } \\
\text { indented maturity level. }\end{array}$ \\
\hline $\begin{array}{l}\text { Erol et al. } \\
(2016)\end{array}$ & $\begin{array}{l}\text { Strategic } \quad \text { guidance } \\
\text { towards } \quad \text { Industry } \\
4.0-\text { a } \\
\text { process model }\end{array}$ & $\begin{array}{l}\text { Development of a vision } \\
\text { for industry } 4.0 \text { remains a } \\
\text { difficult task although many } \\
\text { executives are conscious of } \\
\text { the potential of the business } \\
\text { models and technologies. }\end{array}$ & $\begin{array}{l}\text { The business model is } \\
\text { based on co-innovation } \\
\text { principles and technical path } \\
\text { planning, providing a driving } \\
\text { mechanism for a structured } \\
\text { transformation to Industry } 4.0 \\
\text { vision and strategy. }\end{array}$ \\
\hline $\begin{array}{l}\text { Bahrin et al. } \\
(2016)\end{array}$ & $\begin{array}{llr}\text { Industry } & 4.0: & \text { A } \\
\text { review on } & \text { industrial } \\
\text { automation } & \text { and } \\
\text { robotic } & & \end{array}$ & $\begin{array}{l}\text { The fourth industrial } \\
\text { revolution will be based } \\
\text { on the Internet of things, } \\
\text { cyber-physics systems, and } \\
\text { the Internet of services. In } \\
\text { order to be competitive in } \\
\text { terms of productivity and } \\
\text { economic benefits, more } \\
\text { businesses and states are } \\
\text { joining the movement. }\end{array}$ & $\begin{array}{l}\text { The industry } 4.0 \text { has a high } \\
\text { impact and wide range of } \\
\text { change to manufacturing } \\
\text { processes, outcomes and } \\
\text { business models. }\end{array}$ \\
\hline $\begin{array}{l}\text { Tupa et al. } \\
(2017)\end{array}$ & $\begin{array}{l}\text { Aspects of risk } \\
\mathrm{m} \text { a } \mathrm{n} \text { a g e } \mathrm{m} \text { e } \mathrm{n} \mathrm{t} \\
\text { implementation for } \\
\text { industry } 4.0\end{array}$ & $\begin{array}{l}\text { Information safety } \\
\text { relates to the majority of } \\
\text { common risk factors in } \\
\text { manufacturing field. These } \\
\text { dangers are linked to cyber- } \\
\text { attacks, integrity loss, etc. }\end{array}$ & $\begin{array}{l}\text { New facilities and adaptations } \\
\text { to information handling are } \\
\text { required because of the need } \\
\text { for increased volumes of data } \\
\text { and real time availability. }\end{array}$ \\
\hline
\end{tabular}




\begin{tabular}{|c|c|c|c|}
\hline Authors & Topic of Research & Result /Findings & $\begin{array}{c}\text { Conclusion/ } \\
\text { Recommendation }\end{array}$ \\
\hline $\begin{array}{l}\text { Pereira \& } \\
\text { Romero } \\
(2017)\end{array}$ & $\begin{array}{l}\text { A review of the } \\
\text { meanings and the } \\
\text { implications of the } \\
\text { industry } 4.0 \text { concept. }\end{array}$ & $\begin{array}{l}\text { To make operations more } \\
\text { effective and profitable, } \\
\text { companies moving into } \\
\text { Industry } 4.0 \text { must know any } \\
\text { factor which can be affected } \\
\text { and the key consequences, } \\
\text { but also the opportunities } \\
\text { for innovation }\end{array}$ & $\begin{array}{l}\text { Companies moving into } \\
\text { Industry } 4.0 \text { must be } \\
\text { mindful of every area they } \\
\text { can affect and what their } \\
\text { key consequences are but } \\
\text { also of the potential for } \\
\text { improvement in order to } \\
\text { achieve better process quality } \\
\text { and productivity }\end{array}$ \\
\hline $\begin{array}{l}\text { Baena et al. } \\
(2017)\end{array}$ & $\begin{array}{l}\text { Learning factory: The } \\
\text { path to industry } 4.0\end{array}$ & $\begin{array}{l}\text { Teamworkand coordination } \\
\text { are the most frequent ties } \\
\text { for engineering expertise. } \\
\text { However, since they lack } \\
\text { practical strategies that } \\
\text { help them build know-how } \\
\text { based on experience, their } \\
\text { submission is not clear. }\end{array}$ & $\begin{array}{l}\text { The connection between } \\
\text { learning strategies and } \\
\text { latest manufacturing trends } \\
\text { enhances training, research, } \\
\text { and training in various } \\
\text { engineering fields. }\end{array}$ \\
\hline $\begin{array}{l}\text { Müller et al. } \\
(2018)\end{array}$ & $\begin{array}{l}\text { What drives the } \\
\text { implementation of } \\
\text { industry } 4.0 \text { ? The } \\
\text { role of opportunities } \\
\text { and challenges } \\
\text { in the context of } \\
\text { sustainability. }\end{array}$ & $\begin{array}{l}\text { The companies have } \\
\text { stronger relations to } \\
\text { opportunities } \\
\text { challenges with their } \\
\text { tendencies to implement } \\
\text { Industry 4.0. }\end{array}$ & $\begin{array}{l}\text { The adoption of Industry } 4.0 \\
\text { will be optimistic drivers } \\
\text { of economic, financial, } \\
\text { environmental and social } \\
\text { potential, while the obstacles } \\
\text { relating to profitability, future } \\
\text { feasibility and organizational } \\
\text { development can occur. }\end{array}$ \\
\hline $\begin{array}{l}\text { Hamzeh et al. } \\
(2018)\end{array}$ & $\begin{array}{llr}\text { A } & \text { survey } & \text { study } \\
\text { on } & \text { industry } & 4.0 \\
\text { for } & \text { New } & \text { Zealand } \\
\text { manufacturing }\end{array}$ & $\begin{array}{l}\text { Manufacturing industries } \\
\text { in New Zealand will use } \\
\text { Industry } 4.0 \text { to update and } \\
\text { transform SMEs. }\end{array}$ & $\begin{array}{l}\text { The model requires some } \\
\text { extensions by considering } \\
\text { more detailed sub-steps. }\end{array}$ \\
\hline $\begin{array}{l}\text { Ślusarczyk } \\
(2018)\end{array}$ & $\begin{array}{l}\text { Industry } 4.0 \text { - Are we } \\
\text { ready? }\end{array}$ & $\begin{array}{l}\text { Industry } 4.0 \text { is a great } \\
\text { opportunity to develop and } \\
\text { enhance competitiveness, } \\
\text { while preparedness varied } \\
\text { depending on country, } \\
\text { industry and even an } \\
\text { individual business. }\end{array}$ & $\begin{array}{l}\text { By developing new business } \\
\text { models, the implementation } \\
\text { of this industry } 4.0 \text { will have } \\
\text { further consequences for } \\
\text { management and future jobs. }\end{array}$ \\
\hline $\begin{array}{l}\text { Elena et al. } \\
(2018)\end{array}$ & $\begin{array}{l}\text { Exploring the future } \\
\text { of Russia's economy } \\
\text { and markets }\end{array}$ & $\begin{array}{l}\text { Industry } 4.0 \text { is the most } \\
\text { important direction for } \\
\text { Russia's modernization } \\
\text { of the economy, it makes } \\
\text { possible to achieve } \\
\text { sustainable industrial } \\
\text { and innovative economic } \\
\text { development. }\end{array}$ & $\begin{array}{l}\text { Assessment and proposed } \\
\text { approach should be focused } \\
\text { on during the execution of } \\
\text { this plan. }\end{array}$ \\
\hline
\end{tabular}




\begin{tabular}{|c|c|c|c|}
\hline Authors & Topic of Research & Result /Findings & $\begin{array}{c}\text { Conclusion/ } \\
\text { Recommendation }\end{array}$ \\
\hline $\begin{array}{l}\text { Popkova et al. } \\
\text { (2018) }\end{array}$ & $\begin{array}{l}\text { Exploring the future } \\
\text { of Russia's economy } \\
\text { and markets article } \\
\text { information: Will } \\
\text { industry } 4.0 \text { and } \\
\text { other innovations } \\
\text { impact Russia's } \\
\text { development? }\end{array}$ & $\begin{array}{l}\text { Industry } 4.0 \text { is recognized } \\
\text { as a great opportunity } \\
\text { to improve and enhance } \\
\text { competitiveness } \\
\text { industries, firms by } \\
\text { individuals. }\end{array}$ & $\begin{array}{l}\text { Emphasis should be on } \\
\text { reviewing the way the system } \\
\text { was applied and the approach } \\
\text { offered. }\end{array}$ \\
\hline $\begin{array}{l}\text { Piccarozzi et } \\
\text { al. }(2018)\end{array}$ & $\begin{array}{l}\text { Industry } 4.0 \text { in } \\
\text { management studies: } \\
\text { A systematic literature } \\
\text { review }\end{array}$ & $\begin{array}{l}\text { The paper includes some } \\
\text { business implications to } \\
\text { help businesses incorporate } \\
\text { the report, as this is the } \\
\text { first document that reflects } \\
\text { on Industry } 4.0 \text { business } \\
\text { facets. }\end{array}$ & $\begin{array}{l}\text { This research will provide } \\
\text { entrepreneurs with a more } \\
\text { efficient understanding } \\
\text { and interplay with the } \\
\text { ramifications and fields of } \\
\text { application of the fourth } \\
\text { industrial revolution. }\end{array}$ \\
\hline $\begin{array}{l}\text { Ibarra et al. } \\
(2018)\end{array}$ & $\begin{array}{lr}\text { Business } & \text { model } \\
\text { innovation } & \text { through } \\
\text { Industry } & 4.0: \quad \mathrm{A} \\
\text { Review } & \end{array}$ & $\begin{array}{l}\text { The accompanying paper } \\
\text { provides a short literary } \\
\text { overview to improve our } \\
\text { awareness of the effect } \\
\text { of industry } 4.0 \text { on market } \\
\text { models and the subsequent } \\
\text { creative business models. }\end{array}$ & $\begin{array}{l}\text { Ultimately, more work was } \\
\text { required to provide a better } \\
\text { understanding of the business } \\
\text { model development cycle and } \\
\text { archetypes resulting from the } \\
\text { application of industry } 4.0 \text { to } \\
\text { the competitive environment. }\end{array}$ \\
\hline $\begin{array}{l}\text { Moeuf et al. } \\
(2018)\end{array}$ & $\begin{array}{l}\text { The industrial } \\
\text { management of SMEs } \\
\text { in the era of industry } \\
4.0\end{array}$ & $\begin{array}{l}\text { SMEs are not exploiting all } \\
\text { Industry } 4.0 \text { resources and } \\
\text { are frequently confined to } \\
\text { adopting cloud computing } \\
\text { and the Internet. }\end{array}$ & $\begin{array}{l}\text { Further work will also be } \\
\text { carried out to see whether } \\
\text { business } 4.0 \text { programs will } \\
\text { offer benefits or not. }\end{array}$ \\
\hline $\begin{array}{l}\text { Veile et al. } \\
(2019)\end{array}$ & $\begin{array}{l}\text { Lessons learned } \\
\text { from Industry } 4.0 \\
\mathrm{implementation} \\
\text { in the German } \\
\mathrm{m} \text { an u f c t uring } \\
\text { industry }\end{array}$ & $\begin{array}{l}\text { Developing industry } 4.0 \\
\text { expertise, secure financial } \\
\text { resources integrate } \\
\text { employees into the process } \\
\text { of implementation, create } \\
\text { an open-minded and flexible } \\
\text { company culture are crucial } \\
\text { aspects for implementation } \\
\text { of industry } 4.0 .\end{array}$ & $\begin{array}{l}\text { Given aspects supports } \\
\text { managers in their } \\
\text { organizations to effectively } \\
\text { implement Industry } 4.0\end{array}$ \\
\hline $\begin{array}{l}\text { Machado et } \\
\text { al. (2019) }\end{array}$ & $\begin{array}{l}\mathrm{S} \mathrm{u} \mathrm{s} \mathrm{t} \mathrm{a} \mathrm{i} \mathrm{n} \mathrm{a} \mathrm{b} 1 \mathrm{e} \\
\text { manufacturing } \quad \text { in } \\
\text { Industry } 4.0: \quad \text { an } \\
\text { emerging } \quad \text { research } \\
\text { agenda }\end{array}$ & $\begin{array}{l}\text { A topic of industry } 4.0 \text { is } \\
\text { the convergence between } \\
\text { sustainable production }\end{array}$ & $\begin{array}{l}\text { Industry } 4.0 \text { will have an } \\
\text { interconnected and beneficial } \\
\text { effect on all aspects of } \\
\text { production through the } \\
\text { principles of circular } \\
\text { technology and the utilization } \\
\text { of emerging technologies. }\end{array}$ \\
\hline
\end{tabular}




\begin{tabular}{|l|l|l|l|}
\hline \multicolumn{1}{|c|}{ Authors } & \multicolumn{1}{|c|}{ Topic of Research } & \multicolumn{1}{c|}{ Result /Findings } & \multicolumn{1}{c|}{$\begin{array}{c}\text { Conclusion/ } \\
\text { Recommendation }\end{array}$} \\
\hline $\begin{array}{l}\text { Buchi et al. } \\
(2020)\end{array}$ & $\begin{array}{l}\text { Smart factory } \\
\text { performance and } \\
\text { Industry 4.0 }\end{array}$ & $\begin{array}{l}\text { The study explores causal } \\
\text { association between } \\
\text { degree of openness and } \\
\text { performance, and analyzes } \\
\text { an observational sample of } \\
\text { local production units. }\end{array}$ & $\begin{array}{l}\text { Transparency contributes } \\
\text { to better jobs in the } \\
\text { manufacturing sector, while } \\
\text { smaller local groups will get } \\
\text { more incentives. }\end{array}$ \\
\hline
\end{tabular}

\section{Theoretical and Conceptual Debate}

Industry 4.0 is a development led by technology in a variety of manufacturing companies in which the concept of disruptive innovation is important to study and understand (Nyberg, Nilsen, \& Freilich, 2016). On the foundation of literature, it is important to look at another concept in connection with the management of new technologies, the innovation model, with the description and distinction of 'technology'. Looking from technology management perspective, particularly when new products and procedures are linked to a specific technical model, businesses have trouble handling technological innovations. The transition from hierarchical, isolated to distributed, networked computer architecture is an example of a technical paradigm shift (Thorsten, 2005).

Rogers argues that diffusion is the mechanism by which knowledge is transmitted throughout the period to the social system participants. Rogers et al. (2019) propose that four key elements influence the spread of a new idea: innovation itself, communication channels, time, and the social system. The concept of the value chain of Porter suggests that the competitive advantage of the company cannot be considered in general - the internal structure of the business must also be understood. Tornatzky and Fleisher (1990) have developed the Technology Organization Environment (TOE) model which discusses the factors that influence the acceptance of technology and its probability. TOE explains the process through which technological innovation is adopted and implemented by the company and is influenced by the technological context, the organization and the environmental context (Oliveira \& Martins, 2010).

\section{Figure 1: Conceptual Framework}

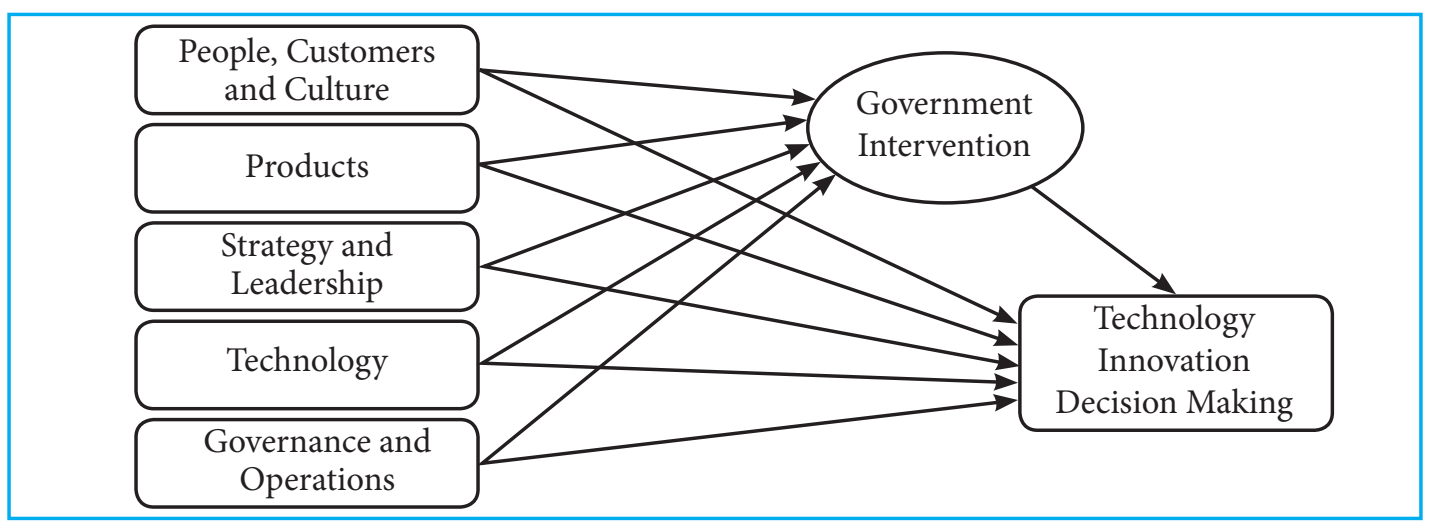

Source: Modified from (Ullah, 2017and Eilu, 2018).

In relation to the fourth industrial revolution we see the development of an industry as progress on domestic and external factors promoting the basic concepts of Industry 4.0, such as the vertical and horizontal convergence of production systems and companies, as well as the incorporation of innovation in digital technology over the entire value chain (Schumacher et al., 2016). In their study, Schumacher et al. (2016) developed the framework for maturity model which is divided into 9 dimension and 62 
maturity items. Schumacher's model is modified and developed where five dimensions: Governance and operations, Technology, Products, Strategy and Leadership, and People, Customers and culture are included.

Similarly, the concept of Technology Organization Environment (TOE) framework which talked about the environment that affects the technology innovation decision is applied. Ullah (2017) mentioned that government intervention plays mediating role in between environmental factors and technology innovation decision.

\section{Discussion and Research Gap}

Nepal is still struggling to resist economic transition. Poor productive potential has contributed to low rates of economic growth and per capita income, and a large percentage of the labor is still engaged in low-productive agricultural practices. With the industrial sector stagnating and low potential for labor utilization in the service sector, there are no economic replacements to boost household well-being. Consequently, in search of better employment, a substantial number of workers choose to migrate to international labor markets (Basnet et al., 2014).

Agriculture remains the main economic activity in Nepal (Devkota et al., 2018) employing nearly 65 percent of the population and generating highest percent of GDP. However, the agricultural sector's contribution to GDP decreases steadily each year, while that of the non-agricultural sector increasing. Non- agriculture sectors includes industry, Wholesale and retail trade, Real estate and business service, construction and others. Wholesale and retail trade will have the highest GDP contribution FY 2018/19, with 23.1 percentage. In the same way, the contribution of agriculture and forest areas, real estate, is calculated so industrial, construction, manufacturing, and other GDP services will be 19.7, 10.4 per cent, 10.3 percent, 6.5 percent, and 31.7 percent respectively (Economic survey, 2018/2019). The average annual growth rate of Nepalese economy is 4.6 percent since the last decade. Where, annual growth rate of agriculture and non-agriculture sectors are 3.1 percent and 5.3 percent respectively.

The probable effect of Industry 4.0 technologies on Nepal's future job market is on dilemma in the presence of broad unorganized workforce, informal jobs, self-employment, and the temporary workers in the organized sector. Several studies support the possible effect of I4.0 technologies on selected sectors such as integrated manufacturing and service, financial, legal, IT, and BPO services. This is partly due to the low relative cost of restrictions on jobs and infrastructure (Mehta, 2019).

According to the McKinsey Global Institute survey, the manufacturing sector has the highest automation capacity (67\%). Similarly, Storage and transportation facilitates 61 percentages and accommodation and food facilities 66 percentage. Some other reports have highlighted that jobs consist of numerous tasks, each of which requires a combination of specific skills and competencies (ILO, 2012). Consequently, the possible effect of emerging technology or automation can be seen by occupations apart from business or sectors in the light of their skill level.

National labor force 2017/18 is used to assess skill of labor to have understanding on potentiality of new technology implementation. Almost one third of total workers in Nepal are involved in Service and sales occupation $(23.8 \%)$, closely followed by Elementary occupation $(20.3 \%)$, while relatively less in craft and related occupation (19.6\%), skilled agriculture, forestry and fishery occupation (13.7\%), professionals $(8.2 \%)$, Plant and machines operators and assemblers $(5.4 \%)$, Technicians and associated professionals (4.4\%), Critical support workers (3.1\%), Managers ( $1.2 \%)$ and others $(0.3)$.

Further, we can classify the occupation on the basis of skill level of workers and their tasks required to fulfill; a) High skilled b) Medium skilled c) Low skilled and d) Unskilled. Tasks are specialized for high and medium skilled and for low and unskilled workers mostly tasks are mechanized or routine. The potential for automation should be evaluated accordingly, i.e. with respect to technological viability in the automation of such activities (Ilavarasan, 2017). Therefore unskilled and low skilled jobs have the 
high potential of automation. High and medium-sized professions generally require advanced expertise in analysis and management and are, therefore, less vulnerable to the effects of automation.

High skilled jobs are highly paid, these jobs comprise managers, professional, technical and professional associates. Small- and medium-sized jobs are primarily found in the organized sector and aspired by the majority of young people in the world. Many of the occupations that have a higher potential for automation currently occur in areas such as information, electro-technology and communication, development, business and financial sectors (ILO,2012) .

Low-skilled and untrained professions, on the other hand, include operational knowledge and routine or manual work, which can be automated easily by new technologies. These are low salaries that involve staff for clerical assistance, supplies that distribution, design and associated enterprises, operators of machinery and assemblies, professions of armed forces and primary professions such as nurses, domestic help employees, guardians of homes, porters, waste collectors (Mehta, 2019).

Most of workers are still in forestry, agriculture and fishery sectors (21.5\%), which is mostly operated with traditional skills. It is suggested that, because of farmers' weak ability or educational qualifications, the speed of implementation of modern technology or the prospect of automation capacity in the agriculture sector will be very sluggish. Similarly, wholesale \& retail trade, repair of motor vehicles $(17.5 \%)$, manufacturing $(15.1 \%)$, construction $(13.8 \%)$, education $(7.9)$, information and communication $(0.9 \%)$ and so on.

The study above indicates that emerging innovations have an adverse effect on net job figures is likely to be marginal in the short term because of the low labor intensity of high automation and industries. But in the longer term and the future, the likely impact of this is much higher by increasing new forms of work and demand for skills. This benefits those with the necessary skills, ability, knowledge and skills.

Above data states that more than $50 \%$ of the peoples are engage in agriculture, forestry and fishery, wholesale \& retail trade, construction and manufacturing most of based on traditional skills. Similarly, only about $13 \%$ of total workers are in high skilled job category, most of them are low and unskilled workers in agriculture, sales workers, and elementary workers. Also the proportion of unskilled and low skilled workers is very high related to high skilled workers.

\section{Conclusion}

Through reviewing various literatures, this study concludes thatNepal has huge unskilled workers relatively to skilled workers that are means there is high potentiality for adaptation of new technologies, replacing daily routine previously operated by unskilled manpower. Similarly, Nepalese organizations have higher possibility for adaptation of new technologies but their routine and other machines works are still operated by unskilled and low skilled works this indicates organizations not so ready for adaptation of new technologies in their industry. We recommend that the government has to focus more on how the concept of Industry 4.0 can be adopted, which in the long run will help for the overall prosperity of the nation.

\section{Conflict of Interest}

No conflict of interest exists between authors while preparing this article.

\section{References}

B. K., A., Devkota, N., Gautam, N., \&Paija, N. (2019). Industry willingness to pay for adequate electricity supply: a discourse on sustainable industrial development. Quest Journal of Management and Social Sciences, 1(2), 251-259. 
Baena, F., Guarin, A., Mora, J., Sauza, J., \&Retat, S. (2017). Learning factory: The path to industry 4.0. Procedia manufacturing, 9, 73-80. https://doi.org/10.1016/j.promfg.2017.04.022

Bahrin, M. A. K., Othman, M. F., Azli, N. H. N., \&Talib, M. F. (2016). Industry 4.0: A review on industrial automation and robotic. Jurnal Teknologi, 78(6-13).

Basnet, Y., Henley G., Howell J., Jones H., Lemma A. \& Pandey, P. (2014). Structural economic transformation in Nepal A diagnostic study submitted to DFID Nepal.

Bauernhansl, T., Ten Hompel, M., \& Vogel-Heuser, B. (Eds.). (2014). Industrie 4.0 in Produktion, Automatisierung und Logistik: Anwendung-Technologien-Migration (pp. 1-648). Wiesbaden: Springer Vieweg.

Büchi, G., Cugno, M., \& Castagnoli, R. (2020). Technological forecasting and social change smart factory performance and industry 4 . 0. Technological Forecasting \& Social Change, 150(June 2019), 119790. https://doi.org/10.1016/j.techfore.2019.119790

Central Bureau of Statistics (CBS), (2014). Development of manufacturing industries in Nepal. Retrieved from https://nada.cbs.gov.np/index.php/catalog/44/download/735.

Daron, A., (2002). Technical change, inequality, and the labor market. Journal of Economic Literature, XL(March), $7-72$.

Devkota, N., Phuyal, R. K., \& Shrestha, D. L. (2018). Perception, determinants and barriers for the adoption of climate change adaptation options among Nepalese rice farmers. Agricultural Sciences, 9(3), 272-298.

Devkota, S., \& Shah, B. P. (2016, October 4). Industry 4.0. My Republica. https://myrepublica.nagariknetwork. com/news/6855/

Economic Survey. (2018). Economic Survey 2018 / 19. Retrieved from https://mof.gov.np/uploads/document/file/ compiled\%20economic\%20Survey\%20english\%207-25_20191111101758.pdf.

Eilu, E. (2018). Adoption of electronic fiscal devices (EFDs) for value-added tax (VAT) collection in Kenya and Tanzania: A systematic review. The African Journal of Information and Communication, (22), 111-134. https://doi.org/10.23962/10539/26169

Elena G. Popkova, Bruno S. Sergi, “Will Industry 4.0 and Other Innovations Impact Russia's Development?” In Exploring the Future of Russia's Economy and Markets. Published online: 22 Oct 2018; 51-68. Permanent link to this document: https://doi.org/10.1108/978-1-78769-397-520181004

Erol, S., Schumacher, A., \& Sihn, W. (2016). Strategic guidance towards Industry 4.0 - a three-stage process model. Coma, (January), 495-501.

Ghimire, S. (2020, February 25). Artificial Intelligence and the Future of Work. Nepal Economic Forum. https:// nepaleconomicforum.org/neftake/artificial-intelligence-and-the-future-of-work/

Hamzeh, R., Zhong, R., \&Xu, X. W. (2018).A survey study on industry 4.0 for New Zealand manufacturing. Procedia Manufacturing, 26, 49-57.

Horváth, D., \& Szabó, R. Z. (2019). Driving forces and barriers of Industry 4.0: Do multinational and small and medium-sized companies have equal opportunities? Technological Forecasting and Social Change, 146(May), 119-132. https://doi.org/10.1016/j.techfore.2019.05.021

Ibarra, D., Ganzarain, J., \&Igartua, J. I. (2018). Business model innovation through industry 4.0: A review. Procedia Manufacturing, 22, 4-10. https://doi.org/10.1016/j.promfg.2018.03.002

Ilavarasan, V. (2017). Automation and workforce in India: Terrible consequences or impossible? SSRN Electronic Journal. https://doi.org/10.2139/ssrn.3038759

Industrial District Management. (2018). Memorial,2018/19.

Jazdi, N. (2014). Cyber physical systems in the context of industry 4.0. 2014 IEEE International Conference on Automation, Quality and Testing, Robotics. https://doi.org/10.1109/aqtr.2014.6857843

Lee, M. H., Yun, J. H. J., Pyka, A., Won, D. K., Kodama, F., Schiuma, G., \& Zhao, X. (2018). How to respond to the Fourth Industrial Revolution, or the second information technology revolution? Dynamic new combinations between technology, market, and society through open innovation. Journal of Open Innovation: Technology, Market, and Complexity, 4(3). https://doi.org/10.3390/joitmc4030021 
Machado, C. G., Winroth, M. P., \& Ribeiro da Silva, E. H. D. (2019). Sustainable manufacturing in Industry 4.0: an emerging research agenda. International Journal of Production Research, 0(0), 1-23. https://doi.org/1 0.1080/00207543.2019.1652777

Mainali, P. K. (2017). Productivity and growth of manufacturing industries in Nepal. (070).

Manandhar, N. (2017, January 23). The Kathmandu Post. https://kathmandupost.com/opinion/2017/01/23/ revolution-no-4

Mehta, B. S., \&Awasthi, I. C. (2019). Industry 4.0 and future of work in India. FIIB Business Review, 8(1), 9-16. https://doi.org/10.1177/2319714519830489

Moeuf, A., Pellerin, R., Lamouri, S., Tamayo-Giraldo, S., \&Barbaray, R. (2018).The industrial management of SMEs in the era of Industry 4.0. International Journal of Production Research, 56(3), 1118-1136.

Müller, J. M., Kiel, D., \& Voigt, K. I. (2018). What drives the implementation of Industry 4.0? The role of opportunities and challenges in the context of sustainability. Sustainability (Switzerland), 10(1). https:// doi.org/10.3390/su10010247

NLFS. (2017). Report on the Nepal Labour Force Survey 2017/18. Central Bureau of Statistics.

Nyberg, E., Nilsen, S., \& Freilich, J. (2016). The adoption of Industry 4.0 technologies in manufacturing - a multiple case study. KTH Industrial Engineering and Management, Master of, 79. https://doi.org/10.1007/ s00464-002-8769-y

Office, I. L. (2012). International Standard Classification of Occupations. International Labour Organization. https://www.ilo.org/wcmsp5/groups/public/---dgreports/---dcomm/---publ/documents/publication/ wcms_172572.pdf

Oliveira, T., \& Martins, M. F. (2010). Information technology adoption models at Firm Level: Review of literature. 4th European Conference on Information Management and Evaluation, ECIME 2010, 14(1), 312-322.

Pereira, A. C., \& Romero, F. (2017). A review of the meanings and the implications of the Industry 4.0 concept. Procedia Manufacturing, 13, 1206-1214. https://doi.org/10.1016/j.promfg.2017.09.032

Piccarozzi, M., Aquilani, B., \&Gatti, C. (2018). Industry 4.0 in management studies: A systematic literature review. Sustainability, 10(10), 3821. https://doi.org/10.3390/su10103821

Popkova, E. G., Sergi, B. S., Popkova, E. G., \& Sergi, B. S. (2018). Exploring the Future of Russia's Economy and Markets Article information : Will Industry 4.0 and Other Innovations Impact Russia's Development?

Qin, J., Liu, Y., \& Grosvenor, R. (2016). A categorical framework of manufacturing for industry 4.0 and beyond. Procedia CIRP, 52, 173-178. https://doi.org/10.1016/j.procir.2016.08.005

Rogers, E. M., Singhal, A., \& Quinlan, M. M. (2019). Diffusion of innovations. In An Integrated Approach to Communication Theory and Research, Third Edition. https://doi.org/10.4324/9780203710753-35

Schmidt, M. Möhring, R.-C. Härting, C. Reichstein, P. Neumaier, and P. J. (2015). Industry 4.0: towards future industrial opportunities and Challenges. Lecture Notes in Business Information Processing, 208, 16-27. https://doi.org/10.1007/978-3-319-19027-3

Schuh, G., Potente, T., \& Hauptvogel, A. (2013). Sustainable increase of overhead productivity due to cyberphysical-systems. 11th Global Conference on Sustainable Manufacturing, 332-335.

Schumacher, A., Erol, S., \& Sihn, W. (2016). A Maturity Model for Assessing Industry 4.0 Readiness and Maturity of Manufacturing Enterprises. Procedia CIRP, 52, 161-166. https://doi.org/10.1016/j.procir.2016.07.040

Ślusarczyk, B. (2018). Industry 4 . 0 - are we ready ?17(1). https://doi.org/10.17512/pjms.2018.17.1.19

Thorsten J. Gerpott. (2005). Strategisches technologie- und innovationsmanagement strategisches technologieund innovationsmanagement. Sammlung Poeschel, 162(January 2005), 13. Retrieved from http://www. researchgate.net/profile/Torsten_Gerpott/publication/200167158_Strategisches_Technologie-_und_ Innovationsmanagement/links/0deec52d3af579bb8d000000.pdf

Tornatzky, L. and Fleisher, M. (1990), The Processes of Technological Innovation, Lexington Books, Lexington, MA.

Tupa, J., Simota, J., \& Steiner, F. (2017). Aspects of risk management implementation for Industry 4.0. Procedia Manufacturing, 11, 1223-1230. 
Ullah, P. S. (2017). Technological factors and adoption of green innovation: Moderating role of government intervention: a case of SMEs in Pakistan.

Veile, J. W., Kiel, D., Müller, J. M., \& Voigt, K. (2019). Lessons learned from industry 4.0 implementation in the German manufacturing industry. Journal of Manufacturing Technology Management, ahead-ofprint(ahead-of-print). https://doi.org/10.1108/jmtm-08-2018-0270

Wan, J., Cai, H., \& Zhou, K. (2015). Industrie 4.0: Enabling technologies. Proceedings of 2015 International Conference on Intelligent Computing and Internet of Things. https://doi.org/10.1109/icaiot.2015.7111555

Wang, S., Wan, J., Li, D., \& Zhang, C. (2016). Implementing Smart Factory of Industrie 4.0: An Outlook. International Journal of Distributed Sensor Networks, 2016. https://doi.org/10.1155/2016/3159805

Weyer, S., Schmitt, M., Ohmer, M., \&Gorecky, D. (2015). Towards industry 4.0 - standardization as the crucial challenge for highly modular, multi-vendor production systems. IFAC-PapersOnLine, 48(3), 579-584. https://doi.org/10.1016/j.ifacol.2015.06.143 